\title{
AMALAN PENULISAN PENGHAKIMAN DAN PELAKSANAANNYA DI MAHKAMAH SYARIAH MALAYSIA
}

\section{The Practice of Judgement Writing and Its Application in Shariah Court of Malaysia}

\author{
Mastura Razali ${ }^{1}$ \\ Jasni Sulong²
}

\begin{abstract}
The practice of judgement writing is one of the necessary procedures carried out by a judge after trial. This practice is essential for trials at the higher court levels. Therefore, this article explores the history of the judgment writing practice, the significance of judgment writing, and its implementation in Malaysia Shariah Court. This article applies the library research method to gain insight into the practice of judgement writing as applied in the Islamic judiciary institutions. The result of this study has shown that judgment writing has been through various phases of improvement, from the time of the Umayyad Dynasty
\end{abstract}

\footnotetext{
Master Candidate, School of Humanities, Universiti Sains Malaysia, 11800 Penang,mahligai_mas86@yahoo.com

2 Senior Lecturer, School of Humanities, Universiti Sains Malaysia, 11800 Penang, jasni@usm.my
} 
up until the present day. In addition, this study also found that the practice of judgment writing has now become a requisite in order to achieve justice and equality in law.

Keywords: judgement writing, the practice of judgement writing

\section{PENDAHULUAN}

Dalam setiap penghakiman perlu adanya keadilan dan kesaksamaan. Oleh itu, untuk membuktikan sesuatu kes yang dibicarakan mencapai kebenaran dan keadilan yang dituntut maka kaedah penghakiman yang cekap dan sempurna perlu dilaksanakan. Oleh itu, penulisan penghakiman merupakan suatu prosedur yang sangat penting yang mesti ada dalam proses penghakiman di setiap mahkamah di Malaysia. Justeru, penulisan penghakiman menjadi satu keperluan dalam sistem kehakiman Islam pada zaman kini. Di samping itu, kewibawaan, kebijaksanaan dan sandaran hujah seorang hakim dalam menanggapi isu yang sedang dibicarakan dapat dinilai daripada analisis dan dapatan dalam penulisan penghakiman yang dihasilkan.

\section{PENULISAN PENGHAKIMAN DALAM ISLAM}

Penulisan penghakiman merupakan prosedur penting dalam sistem kehakiman Islam agar keadilan dapat diwujudkan khususnya pada zaman global kini. Situasi kini amat berbeza dengan dahulu, hakim pada zaman keagungan Islam dahulu terdiri daripada kalangan sahabat yang warak, bertaqwa serta mengetahui dengan mendalam selok belok hukum-hakam Islam sehingga menyebabkan penulisan penghakiman tersebut tidak menjadi keperluan dalam prosedur penghakiman. ${ }^{3}$ Bahkan pada zaman Khulafā' 'al-Rāsyidīn masih tidak terdapat peruntukan khusus berkaitan dengan langkah-langkah perbicaraan dan sebagainya. ${ }^{4}$

Selain itu juga, sistem keadilan pada zaman keagungan Islam tidak begitu rumit seperti mana yang ada sekarang. Ini kerana hakim yang membuat penghakiman itu juga merupakan orang yang bertindak dalam melaksanakan hukuman. Dalam situasi ini maka tidak menjadi keperluan kepada hakim untuk menulis penghakiman. ${ }^{5}$ Seperti zaman Rasulullah SAW, Baginda sendiri

3 Amin al-Jarumi, Prinsip-Prinsip Prosiding Mahkamah dalam Syariat Islam (Shah Alam: Pusat Penerbitan Universiti UiTM, 2006), 240-241.

4 Daud Muhammad, 'Penulisan Teks Penghakiman di Mahkamah Syariah: Kaedah dan Pendekatan' dalam Penulisan Teks Penghakiman di Mahkamah Syariah, ed. Ruzman Md. Noor (Kuala Lumpur: Penerbit Universiti Malaya, 2008), 21.

5 Amin al-Jarumi, Prinsip-Prinsip Prosiding Mahkamah dalam Syariat Islam, 241. 
mendengar kes-kes yang diadukan dan tidak terdapat banyak kes yang berlaku pada masa itu. Kebanyakkan keputusan kes merupakan sebahagian daripada fatwa dengan kedua-dua pihak yang bertelingkah menerimanya sebagai suatu keputusan hukuman dan melaksanakannya dengan serta merta tanpa raguragu. ${ }^{6}$ Walau bagaimanapun, proses mencatat dalam apa jua perkara adalah sangat penting berdasarkan dalil-dalil daripada al-Quran dan Hadīth.

\section{Al-Quran}

Terdapat beberapa dalil al-Quran yang berkisar mengenai keharusan dalam membuat catatan atau penulisan dalam Islam. Dalil-dalil berikut ialah firman Allah SWT yang mengharuskan catatan mengenai hutang dilakukan.

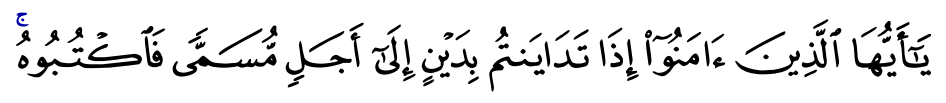

"Wahai orang-orang yang beriman, apabila kamu menjalankan sesuatu urusan dengan hutang piutang yang diberi tempoh hingga ke suatu masa tertentu, maka hendaklah kamu menulis (hutang dan masa bayarannya) itu."

(Surah al-Baqarah, 2: 282)

Daripada ayat di atas, jelas Allah SWT mengarahkan pihak-pihak yang terbabit dalam urusniaga supaya mencatatkannya. Ini kerana dokumen ini boleh digunakan sebagai bukti apabila berlakunya sebarang pertikaian. ${ }^{7}$ Tujuannya jika terdapat pertikaian, bukti bertulis boleh dirujuk. Maka demikian juga jika keputusan kehakiman mendapat pertikaian ke mahkamah yang lebih tinggi, penulisan alasan penghakiman dapat dijadikan sandaran hujah. Firman Allah SWT:

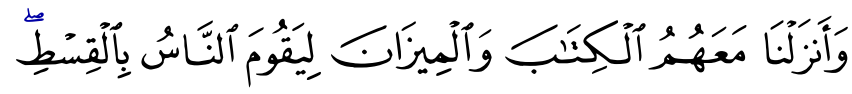

"Dan Kami telah menurunkan bersama-sama mereka Kitab Suci dan keterangan yang menjadi neraca keadilan, supaya manusia dapat menjalankan keadilan."

(Surah al-Hadīì, 57: 25)

6 Daud Muhammad, 'Penulisan Teks Penghakiman di Mahkamah Syariah: Kaedah dan Pendekatan,' 21.

7 'Imad al-Dīn Abī al-Fida' Isma'īl Ibn 'Umar Ibn Kathīr, Tafsīr al-Qur'ān al'Ażìm: al-Ma'rūf bī Tafsīr Ibn Kathīr, vol. 1 (al-Riyāḍ: Dār al-Salām li al-Nashr wa al-Tawzī', 2004), 462. 
Ayat ini jelas memerintahkan supaya semua manusia melaksanakan keadilan termasuk hakim, pendakwa, peguam dan sesiapa sahaja. Keadilan yang perlu ditegakkan meliputi semua aspek dan bidang termasuklah dari segi mendengar perbicaraan, memutuskan $\mathrm{kes}^{8}$ dan menulis penghakiman kerana penulisan yang baik dan lengkap dapat memberi keadilan kepada pihak-pihak sekiranya ingin membuat rayuan. ${ }^{9}$

\section{Hadis}

Hadis Rasulullah SAW juga menekankan aspek penulisan. Walaupun masih tidak wujud penulisan penghakiman pada masa tersebut, namun telah wujud penulisan berkenaan dengan hukum dan fatwa. Bukti yang menunjukkan wujudnya penulisan hukum dan fatwa telah berlaku antaranya riwayat alDahhāk Ibn Sufyān bahawa Rasulullah SAW telah mengutuskan surat kepadanya yang menjelaskan tentang kes Ashyam al-Dibābī yang mana diyat dalam kes itu diberikan kepada isterinya sebagai pusaka.

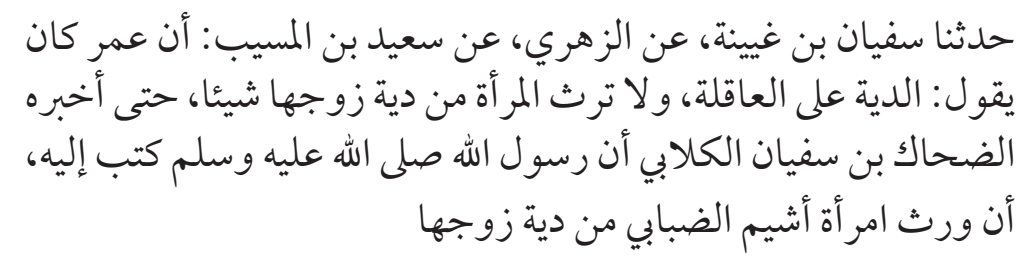

"Telah diceritakan oleh Sufyān Ibn Quyaiyanah daripada azZuhrī, daripada Sa 'ìd Ibn al-Musayyab: Bahawa 'Umar berkata, "Diyat wajib dibayar kerabat pembunuh dan orang perempuan (isteri) tidak dapat menerima pusaka dari diyat suaminya." sehingga ad-Dhahhāk Ibn Sufyān al-Kilābī memberitahukan kepadanya bahawa Rasulullah SAW pernah menulis kepadanya, sesungguhnya hendaklah engkau memberi pusaka kepada isteri Ashyam al-Dibābì dari diyat suaminya'." 10

8 Daud Muhammad, 'Peguam Syarie dalam Institusi Qada,' Jurnal Hukum, 26/2 (2008): 139.

9 Ahmad Hidayat Buang, 'Penulisan Teks Penghakiman dalam Perundangan Islam,' dalam Penulisan Teks Penghakiman di Mahkamah Syariah, ed. Ruzman Md. Noor (Kuala Lumpur: Universiti Malaya, 2008), 15.

10 Hadīth riwayat al-Tirmidhī dan Abī Dāud. Dipetik daripada Muhammad Ibn 'Abd Allāh al-Khātib al-Tibriz̄̄, Miskhāt al-Maṣābih, vol. 2 (Beirūt: al-Maktab alIslāmī, 1996), 922. 
Dalam hadis ini, menunjukkan bahawa Rasulullah SAW pernah menulis alasan hukum dan fatwa mengenai diyat dalam kes pembunuhan. Antara hadis lain, diriwayatkan oleh Abū Hurayrah RA ketika pembukaan Makkah:

$$
\begin{aligned}
& \text { ومن قتل له قتيل فهو بخير النظرين · إما أن يفدى وإمّا أن يقتل . فقام أبو }
\end{aligned}
$$

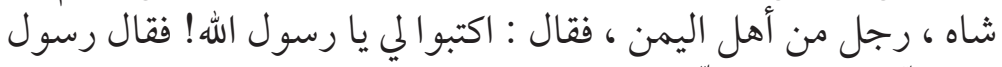

$$
\begin{aligned}
& \text { الله صلّل الله عليه وسلّم : اكتبو اللأبي شاه }
\end{aligned}
$$

"Sesiapa (pihak keluarga yang kena bunuh) yang mempunyai hak ke atas pembunuh, maka dia ada dua pilihan sama ada meminta supaya dibayar diyyat atau dibunuh balas (ke atas pembunuh)." seorang penduduk Yaman dikenali dengan panggilan Abu Shāh bangun dan berkata "Duhai Rasulullah SAW, catatkan kepadaku (apa yang kamu sabdakan itu). Justeru Rasulullah SAW mengarahkan penulis Baginda membuat catatan untuk Abu Shāh." 11

Dalam peristiwa itu, Rasulullah SAW telah memberi arahan supaya hukuman yang dikenakan ke atas jenayah membunuh hendaklah dicatatkan. Arahan ini menunjukkan ia dibuat dengan tujuan supaya dapat disimpan, diingati serta digunakan apabila diperlukan. Maka dengan itu catatan menjadi suatu yang disyariatkan dan boleh dijadikan bukti. ${ }^{12}$

\section{PERKEMBANGAN AMALAN PENULISAN PENGHAKIMAN}

Penulisan penghakiman telah melalui proses perkembangan yang panjang sehingga kini. Walaupun penulisan penghakiman tidak bermula pada zaman Rasulullah SAW akibat daripada larangan penulisan selain daripada al-Quran, tetapi penulisan dalam bentuk catatan telah pun berlangsung pada zaman ini seperti galakan menulis surat hutang. ${ }^{13}$ Penulisan surat hutang ini dapat digunakan sebagai bukti dan keterangan sekiranya berlaku sebarang pertikaian. Jelasnya, penulisan yang boleh menguatkan kes atau sebagai sandaran hujah adalah sangat diperlukan untuk memastikan keadilan dapat ditegakkan. Hal ini kerana, penulisan penghakiman dapat dijadikan sebagai simpanan dan rujukan apabila diperlukan.

11 Abū al-Husayn Muslim Ibn al-Hajjāj Qushayrī al-Naysābūrī, Saḥịh Muslim, Kitāb al-'Ilm, no. Hadis 1355.

12 Amin al-Jarumi, Prinsip-Prinsip Prosiding Mahkamah dalam Syariat Islam, 186.

13 Surah al-Baqarah (2): 282. 


\section{Zaman Rasulullah SAW}

Pada permulaan Islam, pada zaman hayat Rasulullah SAW segala urusan adalah bersumberkan terus kepada Baginda yang akan memberikan panduan dan keputusan berdasarkan sumber wahyu. Ketika itu tidak berlaku sebarang pertikaian berhubung dengan penghakiman yang telah dijalankan. ${ }^{14}$ Justeru penulisan penghakiman pada zaman ini masih tidak diperlukan lagi kerana Rasulullah SAW telah dipandu secara langsung oleh Allah SWT dalam membuat hukuman. Firman Allah SWT:

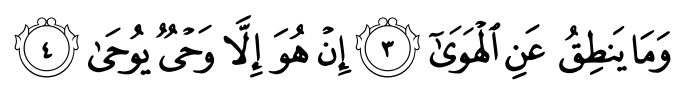

"Dan dia (Nabi SAW) tidak memperkatakan sesuatu menurut hawa nafsu, tidak lain hanyalah wahyu yang diwahyukan kepadanya."

(Surah al-Najm, 53: 3-4)

Menurut Ahmad Muniem, ini jelas menunjukkan hukuman atau keputusan Rasulullah SAW wajib diikuti sama ada ia berdasarkan nas atau ijtihad, sekiranya ijtihad Baginda itu salah maka Allah SWT pasti akan membetulkannya, dengan ini membuktikan bahawa wahyu merupakan sumber perundangan Baginda. ${ }^{15}$

Pentadbiran undang-undang dan kehakiman pada zaman Rasulullah SAW telah berjalan lancar dan licin kerana ia bukan sahaja diketuai oleh Kadi yang bijaksana malah pada masa yang sama Baginda seorang Nabi dan Rasul. ${ }^{16}$ Namun begitu, pada zaman Rasulullah SAW telah berlaku penulisanpenulisan lain seperti peristiwa penulisan hakim kepada hakim yang lain misalnya perintah Rasulullah SAW kepada 'Umar Ibn Hazm tentang hukumhukum dan kadar yang diwajibkan zakat, berkenaan diyat dan farā'id. ${ }^{17} \mathrm{Di}$ samping itu, terdapat juga para sahabat yang menulis apa yang mereka dengar daripada Nabi SAW seperti 'Abd Allāh Ibn 'Umar Ibn al-'As, ${ }^{18}$ berdasarkan hadis Rasulullah SAW:

14 Daud Muhammad, 'Penulisan Teks Penghakiman di Mahkamah Syariah: Kaedah dan Pendekatan,' 20.

15 Aḥmad 'Abd al-Muniem al-Bahai, Tārīkh al-Qadā' fì al-Islām (Mesir: Matba'ah Lajnah al-Bayān al-'Arabī, 1970), 73.

16 Mahmud Saedon Awang Othman, Institusi Pentadbiran Undang-Undang dan Kehakiman Islam (Kuala Lumpur: Dewan Bahasa dan Pustaka, 1996), 44.

17 Abū Ḥassan al-Māwardī, al-Hawī al-Kabìr, vol. 16 (Beirūt: Dār al-Kutub al'Ilmiyyah, 2009), 212.

18 Mohd Saleh Hj Ahmad, Pengantar Syari'at Islam (Selangor: Pustaka Haji Abdul Majid, 2011), 58. 


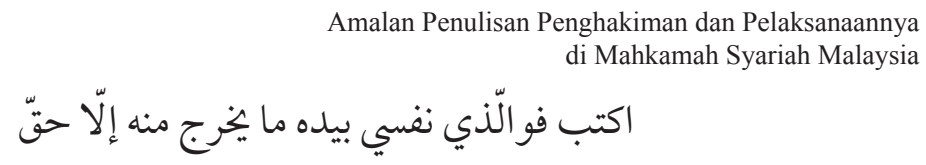

"Kamu tulislah, demi Allah yang diriku dalam kekuasaanNya, tidak ada yang keluar dariku melainkan yang benar." 19

'Abd Allāh Ibn 'Abbās juga menulis bahawa Abū Rāfi' yang merupakan khadam Rasulullah SAW telah menulis apa sahaja yang dituturkan oleh Baginda SAW. ${ }^{20}$

Sesungguhnya riwayat-riwayat ini jelas menunjukkan terdapat sebilangan Sahabat-Sahabat tertentu yang diberi keizinan oleh Rasulullah SAW untuk mencatat setiap apa yang mereka dengar daripada perkataan Baginda, iaitu hadis-hadis yang mana terkandung di dalamnya juga hukuman dan fatwa Rasulullah SAW berdasarkan riwayat Ibn 'Abbās:

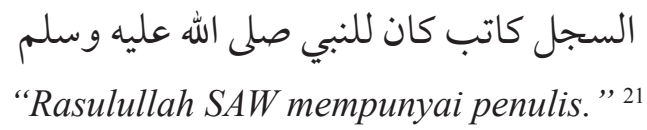

Berdasarkan hadis ini menjelaskan bahawa penulisan itu penting sehinggakan Rasulullah SAW telah mempunyai empat puluh penulis sama ada menulis perkara wahyu atau bukan wahyu. Penulis tersebut terdiri daripada empat Khulafā al-Rāsyidīn, Abī Ka'ab, Zubīr Ibn 'Awām, 'Amīr Ibn Fahīrah, 'Amru ibn 'Ās Mu'āwiyyah Ibn Abī Sufyān, Zayd Ibn Thābit dan ramai lagi. ${ }^{22}$

Kesimpulan daripada penerangan di atas menunjukkan bahawa penulisan penghakiman belum lagi dilaksanakan pada zaman Rasulullah SAW tetapi telah wujud penulisan-penulisan lain yang diamalkan seperti penulisan hukum, catatan kes dan penulisan fatwa. Ini menjelaskan lagi pada zaman tersebut penulisan penghakiman masih lagi belum menjadi keperluan dalam penghakiman Islam.

19 Abū Dāwud Sulaymān Ibn Ash'ath al-Azadī al-Sijistān̄i, Sunan Ab̄̄ Dāwud, Kitāb al-'Ilm, Bab fī Kitāb al-'Ilm, no. Hadis 3646.

20 Ibn Sa'ad, al-Tabaqāt al-Kubrāa, vol. 2 (Beirūt: Dār Sadīr, 1957), 371.

21 Abū Dāwud Sulaymān Ibn Ash'ath al-Azadī al-Sijistānī, Sunan Abī Dāwud, Kitāb al-Kharāj wa al-Imārah wa al-F̄̄, Bab fī Ittikhāzi al-Khātib, no. Hadis 2935.

22 Muhammad 'Abd al-Qādir Abū Fāris, al-Qaḍā' fì al-Islām ('Ammān: Dār alFūrqan, 1995), 60. 


\section{Zaman Sahabat}

Penulisan penghakiman pada zaman sahabat tidak jauh beza dengan zaman Rasulullah SAW. Hal ini kerana selepas kewafatan Rasulullah SAW, para sahabat terutamanya Khulafā' 'al-Rāsyidīn telah menjadi tumpuan dalam segala urusan. Mereka telah mentafsirkan sesuatu kejadian yang berlaku dengan berpandukan masa hayat Rasulullah $\mathrm{SAW}^{23}$ Selain itu, Khulafā' al-Rāsyidìn juga telah menulis arahan-arahan mereka kepada pemerintah-pemerintah dan hakim-hakim mengenai hal ehwal agama dan politik. ${ }^{24}$

Seperti pada zaman pemerintahan Saidina Abū Bakar tidak ada sebarang perubahan yang ketara dari segi penghakiman kerana prosedur perbicaraan atau disebut Niẓām al-Qaḍā' pada ketika itu begitu mudah sekali kerana semua permasalahan dan pertikaian dirujuk kepada Khalifah, ${ }^{25}$ bahkan tidak ada peraturan atau peruntukan khusus berkenaan prosiding perbicaraan dan sebagainya. ${ }^{26}$ Oleh sebab itu, penulisan-penulisan pada zaman ini adalah berkisar tentang hukum, sebagai contoh Saidina Abū Bakar telah memerintahkan 'Anas pergi ke Bahrain untuk mengumpulkan zakat lalu Abū Bakar telah menulis surat sebagai bukti sokongan berkaitan dengan apa yang diperintahkan oleh Allah kepada Rasul-Nya berhubung dengan kewajipan zakat. ${ }^{27}$ Tidak terdapat perubahan yang penting pada zaman Abū Bakar dalam pentadbiran kehakiman dan asasnya kerana negara berhadapan dengan masalah seperti gerakan murtad, pemberontakan terhadap negara dan keengganan mengeluarkan zakat. ${ }^{28}$

Manakala pada zaman 'Umar al-Khattāo pula telah berlaku sedikit perubahan dalam pentadbiran kehakiman. ${ }^{29}$ Beliau telah mewujudkan tiga peringkat mahkamah iaitu mahkamah yang boleh mendengar jika amaun atau nilai hal perkara yang dipertikaikan itu tidak melebihi dua dirham yang dihakimi oleh al-Saib Ibn Yazīd. Mahkamah yang kedua ialah mahkamah yang

23 Daud Muhammad, 'Penulisan Teks Penghakiman di Mahkamah Syariah: Kaedah dan Pendekatan,' 20.

24 Abū Hassan al-Māwardī, al-Hawī al-Kabìr, 212.

25 Muhammad 'Abd al-Qādir Abū Fāris, al-Qadā'fì al-Islām, 78.

26 Daud Muhammad, 'Penulisan Teks Penghakiman di Mahkamah Syariah: Kaedah dan Pendekatan,' 21.

27 Abī Bakr Aḥmad Ibn al-Ḥusayn Ibn 'Alī al-Bayhaqīe, Sunan al-Kabīr, vol. 20 (Qāhirah: t.p, 2011), 378.

28 Ibn al-Qayyim al-Jawziyyah, A 'lām al-Muwaqqi 'īn 'an Rabb al-'Ālamīn, vol. 1 (Qāhirah: Maktabah al-Kulliyyah al-Azhāriyyah, 1968), 53-54.

29 Daud Muhammad, 'Penulisan Teks Penghakiman di Mahkamah Syariah: Kaedah dan Pendekatan,’ 21. 
mempunyai bidang kuasa yang luas berbanding mahkamah yang pertama dan dihakimi oleh 'Alī Ibn Abī Țālib dan Zayd bin Thābit. Manakala mahkamah yang ketiga ialah merupakan Mahkamah Rayuan yang dikendalikan oleh Saidina 'Umar sendiri. ${ }^{30}$ Walaupun telah wujud Mahkamah Rayuan pada masa itu namun tidak ditemui penulisan penghakiman. Hal ini kerana, amalan kehakiman pada zaman tersebut ialah dengan menjemput kembali hakimhakim yang telah membicarakan kes sebagai contoh 'Alī dan Zayd dipanggil untuk bersama-sama menyemak semula kes jika perlu. ${ }^{31}$ Pada masa ini, telah wujud penulisan risalah kehakiman yang telah dihantar oleh Saidina 'Umar al-Khațtāb kepada Kadi Abū Mūsa al-Asy'arī yang terkandung di dalamnya peraturan-peraturan atau prosedur perbicaraan atau boleh dianggap sebagai alNiz̄àm al-Qaḍa 'al-Islāmī iaitu. Antara isi kandungan risalah tersebut ialah:

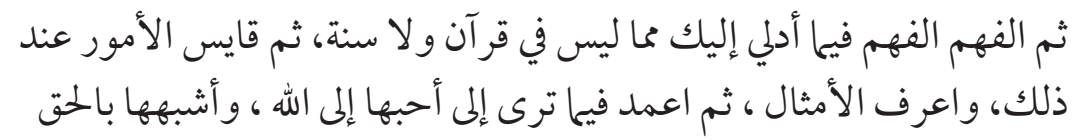

"Fahamilah dengan sebenar-benar kefahaman perkaraperkara yang dihadapkan kepada kamu, terutamanya yang tidak disebut secara jelas dalam al-Quran dan Hadith, kemudian qiyāskanlah perkara-perkara yang sebanding dengannya, pastikan persamannya, kemudian berpeganglah kepada sesuatu yang kamu lihat lebih dicintai (diredhai) oleh Allah dan lebih menyerupai (mendekati) kebenaran." 32

Tambahan lagi, proses pemberian hukum pada zaman para sahabat juga kebanyakannya berlaku secara langsung apabila diajukan pertanyaan atau persoalan berkaitan tentang sesuatu isu. Sebagai contoh, peristiwa berlaku pada zaman Saidina 'Umar di mana beliau melarang orang ramai daripada meninggikan kadar mahar iaitu tidak boleh melebihi empat dirham, katanya:

30 Farid Sufian Shuaib, Administration of Islamic Law in Malaysia (Kuala Lumpur: Malayan Law Journal Sdn. Bhd., 2001), 170-171; Ibn al-Qayyim al-Jawziyyah, A 'lam al-Muwaqqi ìn An Rabb al- 'Ālamīn, 79.

31 Farid Sufian Shuaib, Administration of Islamic Law in Malaysia, 171.

32 Abū Hassan al-Māwardī, al-Ahkām al-Sulțāniyah wa al-Wilāyah al-Dīnīyah (Qāhirah: Matba’ah Mușțāaà al-Bābī al-Ḥalābī, 1966), 71. 


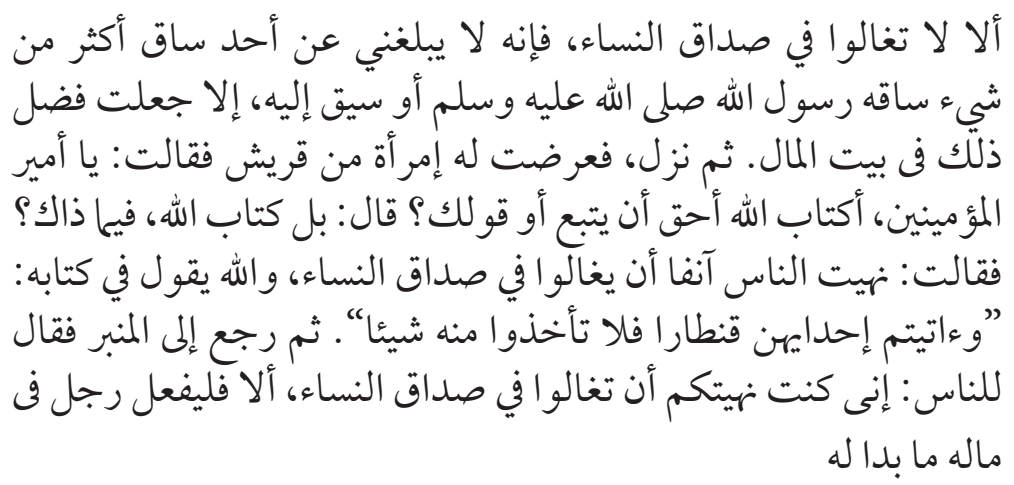

"Ketahuilah, janganlah kamu berlebihan dalam menetapkan mas kahwin wanita, sesungguhnya janganlah sampai kepadaku hal seseorang yang melebihi mas kahwin daripada yang dilakukan Rasulullah SAW, melainkan aku akan jadikan ia untuk baitulmal. Kemudian 'Umar turun dari mimbar, lantas seorang perempuan Quraisy datang membantah sambil berkata: Wahai Amirul Mukminin, adakah Kitab Allah lebih berhak untuk diikuti atau kata-katamu? Jawab 'Umar: Tentu sekali Kitab Allah! Kenapa? Jawab wanita itu: Kamu melarang manusia tadi daripada berlebihan ke atas mas kahwin wanita, sedangkan Allah SWT berfirman dalam Kitab-Nya: Dan berikan setiap mereka (perempuan) satu gugusan harta dan jangan kamu mengambil sesuatu dari haknya. Kemudian 'Umar naik semula ke atas mimbar dan berkata kepada manusia» Tadi aku telah menghalang kamu daripada berlebihan dalam mengenakan mas kahwin wanita, ketahuilah buatlah bagi seorang lelaki apa yang jelas baginya." 33

Mendengar hujah wanita itu, akhirnya Saidina 'Umar membatalkan hasratnya untuk mewujudkan peraturan atau undang-undang bagi menetapkan kadar mahar yang tertentu itu. ${ }^{34}$

Ketika pemerintahan Khalifah 'Uthmān Ibn 'Affān, institusi kehakiman diteruskan sama seperti pemerintahan sebelumnya. Beliau merupakan ketua institusi kehakiman dan rujukan terakhir dalam pentadbiran undang-undang dan kehakiman. Bahkan beliau telah menulis surat kepada penguasa, pegawai

33 Abī Bakr Aḥmad Ibn al-Husayn Ibn 'Alī al-Bayhaqī, Sunan al-Kabīr, Kitāb alȘadāq, Bab Lā Waqta fĩ al-Șadāq Kathura aw Qallaa, no. Hadis 14452.

34 'Imād al-Dīn Abī al-Fidā' Ismā'īl Ibn Kathīr, Tafsīr al-Qur'ān al- 'Aẓ̌im, vol. 2, (Beirūt: Dār al-Andalus, 1966), 230. 
dan mereka yang bertugas agar menegakkan keadilan. Sebagai contoh antara tulisannya ialah:

"Amanah itu tetap amanah. Tegakkanlah amanah itu, janganlah kamu merupakan orang yang mula-mula mencabulnya. Jika kamu melakukannya, bererti kamu menjadi rakan kongsi kepada orang-orang selepas kamu dalam mencabul amanah. Sempurnakanlah, janganlah kamu menzalimi anak yatim dan orang yang mempunyai perjanjian dengan kamu (orang kafir mu'ahid), sesungguhnya sesiapa yang menzalimi mereka bererti telah menjadikan Allah SWT sebagai musuhnya..." 35

Selanjutnya pada zaman Khulafā' al-Rāsyidīn yang terakhir iaitu khalifah 'Alī Ibn Abī Thālib terdapat penulisan-penulisan yang tidak jauh bezanya pada zaman-zaman sebelum itu. Sebagai contoh 'Alī RA juga menulis berkenaan hukuman denda (diyat) termasuk jumlahnya dan jenis-jenisnya. Beliau menulis berkenaan pembebasan orang Islam yang ditawan oleh orang kafir, berkenaan larangan hukuman qisas terhadap orang Islam yang membunuh orang kafir. ${ }^{36}$ Kesimpulannya, pada zaman Sahabat, fungsi perhukuman lebih menonjol daripada fungsi perundangan kerana keperluan kepada undang-undang tidak begitu ketara berbanding dengan keperluan kepada hukuman. Hal ini kerana, cara hidup masyarakat pada masa itu masih mudah dan peraturan-peraturan hidup dilaksanakan secara lebih berasaskan kepada komitmen beragama. ${ }^{37}$ Manakala kaedah penulisan penghakiman pula masih lagi belum diperlukan kerana pada masa tersebut sumber perundangan yang digunakan merupakan sumber-sumber yang disepakati seperti al-Quran, hadis dan ijmak. Bahkan para Sahabat sendiri merupakan individu-individu yang sangat berautoriti dalam memutuskan hukuman. ${ }^{38}$ Justeru, penulisan ${ }^{39}$ yang berlangsung pada zaman ini kebanyakannya berkisar tentang penulisan hukum, penulisan arahan dan surat kepada hakim. ${ }^{40}$

35 Aḥmad Sa'ad 'Alī (ed.), Sunan Abī Dāwud, vol. 2 (Mesir: Muștāfā al-Bābī alHalābī, 1952), 270; Mahmud Saedon Awang Othman, Institusi Pentadbiran Undang-Undang dan Kehakiman Islam, 80-81.

36 M. Syuhudi Ismail, Kaedah Kesahihan Sanad Hadīth (Selangor: Thinker's Library Sdn. Bhd., 1988), 90.

37 Mahmood Zuhdi Abdul Majid, Pengantar Undang-Undang Islam di Malaysia (Kuala Lumpur: Universiti Malaya, 1997), 6.

38 Muhammad 'Abd al-Qādir Abū Fāris, al-Qadā'fì al-Islām, 78.

39 Daud Muhammad, 'Penulisan Teks Penghakiman di Mahkamah Syariah: Kaedah dan Pendekatan,' 21.

40 'Ala al-Dīn al-Tarābulusī, Mu'īn al-Hukkām fìmā Yataraddad bayna al-Khasmayn min al-Ahkām (Qāhirah: Maktabah Muṣțāfā al-Bābī al-Ḥalābī, 1973), 29. 


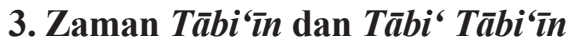

Pada zaman ini telah wujud penulisan penghakiman walaupun masih di peringkat awal disebabkan oleh wujudnya keperluan. Hal ini kerana, bilangan umat Islam yang semakin bertambah dan terdapat beberapa beberapa perselisihan pendapat berhubung penghakiman di mahkamah.

Walau bagaimanapun, tidak terdapat kitab tertentu yang membicarakan kaedah dan pendekatan penulisan penghakiman cuma yang wujud ketika itu hanya garis panduan penghakiman secara umum seperti perbincangan mengenai syarat-syarat lantikan hakim, tempat dan masa perbicaraan, bayaran kepada hakim, jawatan jurutulis mahkamah dan kriteria jurutulis. ${ }^{41}$ Kepentingan penulisan penghakiman pada zaman ini dapat diqiyāskan berdasarkan hadis Rasulullah SAW ketika mengutuskan Saidina 'Ali menjawat jawatan Kadi ke Yaman di mana Rasulullah SAW telah bersabda:

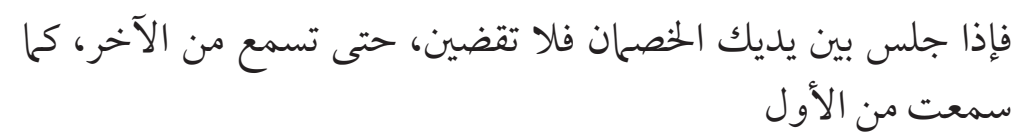

"Apabila datang dua orang yang bertelingkah duduk di hadapan kamu, jangan sekali-kali kamu menghukum sehingga kamu mendengar hujah pihak yang kedua sepertimana yang pertama. " 42

Hadis ini menjelaskan bahawa Rasulullah SAW memberi ingatan kepada semua pihak yang terlibat dengan prosiding perbicaraan di mahkamah supaya memberi perhatian dengan pendengaran dari semua pihak di dalam sesuatu perbicaraan. Dalam keadaan wilayah Islam yang semakin meluas, pendengaran tersebut bukan hanya dengan 'mendengar' sahaja, tetapi mesti disusuli dengan catatan yang lengkap dengan segala keterangan yang diberi semasa perbicaraan supaya ianya dapat dihalusi dan dikaji bagi mendapat keputusan yang tepat. ${ }^{43}$

Perkara ini telah diaplikasikan pada zaman pemerintahan Khalifah 'Umayyah di mana pentadbiran kehakiman pada masa ini telah diperluaskan lagi kerana terdapat banyak perkara-perkara baru yang timbul yang

41 Daud Muhammad, 'Penulisan Teks Penghakiman di Mahkamah Syariah: Kaedah dan Pendekatan,' 20.

42 Abū Dāud Sulaimān ibn Ash 'ath al-Azadī al-Sijistānī, Sunan Abī Dāud, Kitāb al'Aqdiyah, Bab Ijtihād al-Ra'yu fì al-Qadhā', no.Hadīth 3592.

43 Mohd Nadzri Abdul Rahman Ibrahim, Undang-Undang Tatacara Mal Mahkamah Syariah: Prinsip dan Amalan (Negeri Sembilan: Karya Kreatif Resources, 2010), 184. 
memerlukan kepada penyelesaian melalui penghakiman. ${ }^{44}$ Justeru dalam hal ini, hakim telah memainkan peranan sepenuhnya dalam menyelesaikan isuisu berkaitan penghakiman ${ }^{45}$ di samping melakukan penambahbaikan dengan diwujudkan catatan penghakiman bertujuan untuk mengelakkan pihak-pihak yang mendakwa dari mempertikaikan penghakiman yang hanya diberikan secara lisan. ${ }^{46}$

Kemudiannya, pada zaman Khalifah 'Abbasiyyah juga telah mengamalkan penulisan penghakiman yang menghendaki para hakim merekodkan penghakiman. ${ }^{47}$ Bukan setakat keputusan atau hukuman serta alasannya yang perlu ditulis malahan perjalanan perbicaraan juga perlu ditulis atau pada masa ini dikenali sebagai rekod perbicaraan dan keterangan juga hendahlah ditulis nombor giliran kes agar perbicaraan dijalankan mengikut giliran tersebut. Tuntutan yang hendak didengar oleh mahkamah dikehendaki agar didaftarkan dalam sijil pendaftaran sebelum sesuatu kes itu didengar. Ini bertujuan sebagai persediaan yang perlu diadakan agar perbicaraan berjalan lancar. Maka boleh dikatakan bahawa pada zaman ini telah diwujudkan asas yang kukuh dalam pentadbiran undang-undang dan perbicaraan di mahkamah. ${ }^{48}$

Contoh amalan penulisan penghakiman yang berlaku pada zaman Khalifah 'Abbasiyyah ialah Kadi Salīm Ibn Atar yang bertugas sebagai Kadi Mesir telah menulis keputusan bagi kes-kes yang dikendalikan oleh beliau bertujuan untuk mengelakkan daripada berlakunya pertikaian selepas keputusan ditetapkan. ${ }^{49}$ Sebagai contoh dalam kes pusaka yang mana satu kumpulan telah berselisih faham tentang pusaka, maka Kadi Salīm Ibn Atar telah menghakimi kes itu dengan dijatuhkan hukuman berhubung dengan perkara itu ke atas mereka. Kemudian mereka menafikan hukuman tersebut seterusnya mereka pergi berjumpa Kadi untuk kali kedua. Hukuman tersebut telah ditulis dengan disaksikan oleh pegawai-pegawai dan pembesar-pembesar tentera ketika

\footnotetext{
44 Muhammad 'Abd al-Qādir Abū Fāris, al-Qadā'fì al-Islām, 78.

45 Muhammad 'Abd al-Qādir Abū Fāris, al-Qadā' fì al-Islām, 78.

46 Farid Sufian Shuaib, Administration of Islamic Law in Malaysia, 171; Mahmud Saedon Awang Othman, Institusi Pentadbiran Undang-Undang dan Kehakiman Islam, 90.

47 Farid Sufian Shuaib, Administration of Islamic Law in Malaysia, 171

48 Mahmud Saedon Awang Othman, Institusi Pentadbiran Undang-Undang dan Kehakiman Islam, 93.

49 Muhammad 'Abd al-Rahmān al-Bakr, al-Ṣulțah al-Qadā'iyyah wa Shakhsiyyah al-Qāḍ̂̀ fì al-Niẓām al-Islāmī (Qāhirah: al-Zahrā' li al-I'lām al-'Arabī, 1988), 263.
} 
itu. ${ }^{50}$ Oleh itu, tindakan beliau dalam menulis penghakiman ini telah menjadi ikutan serta turut dilaksanakan oleh hakim-hakim lain dalam kes-kes yang dikendalikan oleh mereka. Selain daripada itu, keputusan penghakiman daripada hakim-hakim seperti Kadi Tāhir, Kadi Ma'mūn dan Kadi Sāhib Ibn 'Abbād juga turut ditulis dan menjadi bahan penulisan klasik. ${ }^{51}$

Keadaan ini mendorong pihak mahkamah mewujudkan jawatan jurutulis untuk mencatat kenyataan pihak-pihak yang berbalah, keterangan saksi, hukuman hakim dan lain-lain. ${ }^{52}$ Jurutulis tersebut mestilah bersifat adil, ${ }^{53}$ kerana pelaksanaan hukuman bergantung pada rekod hukuman yang ditulis oleh jurutulis, mukallaf, mampu menulis dengan baik dan tidak mengelirukan serta seseorang yang mempunyai tulisan yang kemas dan tahu menulis laporan dan merekodkan kenyataan pihak-pihak yang berbalah dalam perbicaraan di mahkamah, tuntutan pihak yang menuntut, pembelaan bagi yang kena tuntut, keterangan dari saksi-saksi, hukuman dan alasan-alasan hakim dan lain-lain yang berkaitan. ${ }^{54}$

Selain itu, terdapat beberapa pandangan para fuqaha silam yang mampu menjadi hujah kepada keperluan penulisan penghakiman. Antaranya pendapat al-Azrāī dan al-Zarkashī mengenai syarat bagi seseorang hakim itu sendiri yang mesti tahu menulis. Justeru, seseorang hakim disyaratkan boleh menulis kerana seseorang itu perlu menulis kepada orang lain dan kebolehan ini dapat mengelakkan berlaku penyelewengan penulis atau pembaca yang membaca keterangan kepada hakim tersebut. ${ }^{55}$ Dengan adanya syarat ini, jelas menunjukkan bahawa perlu dan pentingnya penulisan penghakiman. Tambahan lagi, sesetengah ulama berpendapat menjadi kemestian bagi hakim untuk menyediakan catatan perbicaraan dan keputusan bertulis serta diedarkan

50 Ibrāhīm Najīb Muhammad 'Iwad, al-Qaḍ̄' fì al-Islām Tārikhuhu wa Nizāmuhu (Qāhirah: Majma‘ al-Buhūth al-Islāmiyyah, 1975), 56; Abū Omar Muhammad Ibn Yūsuf Ibn Ya'qūb al-Kindī, Kitāb al-Qudhāt alladhīn wallaw Qadhā' Misr (T.t.p: Madīnah Rumīyyah al-'Izmī, 1908), 10.

51 Salahuddin Khuda Bakhsh, The Renaissance of Islam (Patna: Jubilee Printing and Publishing House, 1937), 232.

52 Muḥammad 'Abd al-Qādir Abū Fāris, al-Qaḍ̄' fí al-Islām, 60 dan 64.

53 Muhammad Idrīs al-Shafi ‘̄̄al, al-Umm, vol. 6 (Beirūt: Dār al-Ma‘rifah, 1973), 210.

54 Abū Hassan al-Māwardī, al-Hawī al-Kabīr, 199; Ghazali Abdullah, Jafril Khalil dan Mohd Nasran Mohammad, 'Isu Syariah dan Undang-Undang' dalam Pengantar Sistem Kehakiman Islam (Kuala Lumpur: Universiti Kebangsaan Malaysia, 1996), 119.

55 Muḥammad al-Syarbinī al-Khatīb, al-Iqnā 'fì Hâall Alfāz Abì Syujā' (t.t.p: t.p., t.t.), 299. 
kepada pihak-pihak yang berjaya, manakala rekod asal disimpan di pejabat mahkamah. ${ }^{56}$ Berdasarkan Perkara 1827 Majallah al-Aḥkām al- 'Adliyyah: ${ }^{57}$

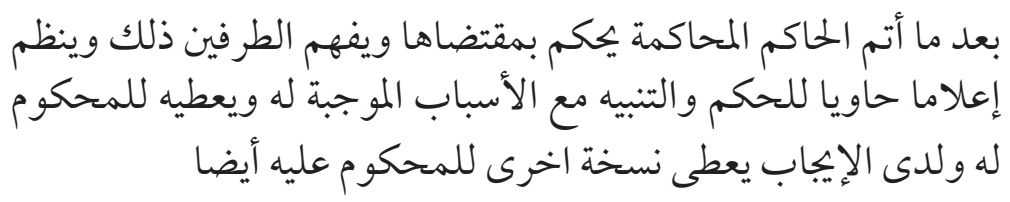

"Setelah hakim mahkamah mensabitkan kesalahan dan keduadua pihak memahami apa yang telah diputuskan oleh hakim yang menyatakan sebab dan alasan pertuduhan yang termaktub dalam fail dan diberikan kepada responden yang memberi respon positif sebaik pertuduhan dibacakan dan salinan dokumen yang lain diberikan kepada defendan."

Dapat difahami dalam kenyataan di atas ialah apabila mahkamah telah selesai membicarakan sesuatu kes maka hakim memberitahu kepada keduadua pihak apa yang perlu dilakukan daripada penghakiman tersebut dan hakim perlu menyediakan penulisan penghakiman yang di dalamnya mengandungi fakta-fakta, perintah dan hukuman serta alasan penghakiman, dan diberikan salinan penghakiman kepada pihak-pihak yang menang dan kalah.

Selain itu, terdapat juga hujah lain yang boleh dikaitkan kepada keperluan pengaplikasian penulisan penghakiman antaranya ialah perbincangan daripada sudut penulisan penghakiman seorang hakim untuk hakim yang lain. Sebagai contoh penulisan penghakiman seorang hakim untuk hakim yang lain yang telah dipetik daripada al-Mughnī karangan Ibn Qudāmah:

"Disebabkan sampai kitab ini kepada hakim-hakim orang muslimin bahawa sabit di majlis penghukuman saya yang saya berbidang kuasa di tempat X(sekiranya bagi pihak maka nyatakan bagi pihak siapa) dengan mahdar (catatan fakta perbicaraan) kedua-dua pihak plaintif dan defenden yang saya berbidang kuasa mendengarnya. Saya telah mendengar keterangan dari kedua-dua pihak dan menerima keterangan salah seorang daripada mereka dengan kesaksian X dan Yyang mana kedua-duanya adalah saksi yang adil. Saya mensabitkan hukuman dengan apa yang terdapat di dalam mahdar ini (sekiranya melibatkan tuntutan hutang maka hendaklah dinyatakan butiran tentang hutang tersebut dan

56 Muhammad al-Syarbinī al-Khatīb, al-Iqnā' fì Hāall Alfāz Abī Syujā', 394-395.

57 Ahmad Jawdah et al., Majallah al-Ahkām al-'Adliyyah (t.t.p: t.p., 1968), 371. 
nama-nama pemiutang dan penghutang serta siapa yang berhak menuntut hutang tersebut). Hukuman ini adalah bertarikh $X$. "58

Seseorang hakim boleh menggunapakai catatan yang berada dalam rekod mahkamah sama ada catatan itu ditulis sendiri oleh hakim atau jurutulis hakim. ${ }^{59}$ Tambahan lagi, menurut al-Māwardī, jika sekiranya telah terdapat peraturan atau penghakiman sebelum ini, maka hakim hendaklah merujuk kepada catatan yang dibuat oleh para jurutulis, jika hakim itu yakin dengan tulisan mereka dan diterimanya daripada para penulis tersebut dengan cop mereka. ${ }^{60} \mathrm{Hal}$ ini menunjukkan bahawa catatan atau penulisan itu penting bagi membantu dalam pembuktian dan rujukan kepada hakim. Seterusnya berkaitan dengan mengenakan bayaran pada hakim yang menulis penghakiman, Jalāl alDīn Abū al-Mahāmid Hamīd Ibn Muhammad berpandangan harus bagi hakim mengambil bayaran atas catatan penghakiman yang dibuat olehnya kerana tugas hakim yang sebenar adalah memberikan hak kepada yang berhak adapun menulis penghakiman itu merupakan tambahan kerja baginya dalam hal penghakiman. ${ }^{61}$ Bayaran yang dikenakan ini menggambarkan tanggungjawab penulisan penghakiman adalah besar dan penting sehingga dibayar dengan gaji tambahan.

Seterusnya, terdapat beberapa pendapat fuqahà' silam yang menyatakan tentang kepentingan penulisan penghakiman. Antaranya pendapat Ibn Abī Dam iaitu tujuan penulisan penghakiman ditulis adalah untuk digunakan sebagai catatan kesaksian kepada hakim lain untuk membuat penghakiman. ${ }^{62}$ Menurut al-Tarābulusī pula, penulisan penghakiman penting untuk ditulis kerana ia akan digunakan oleh hakim bagi tujuan rujukan dan pemeriksaan keterangan terutamanya bagi mengelakkan daripada berlakunya kesilapan sebelum hukuman dijatuhkan. ${ }^{63}$ Selain itu, menurut Ibn Qudāmah, sesuatu

58 Ahmad Hidayat Buang, 'Penulisan Teks Penghakiman dalam Perundangan Islam,' 9; Muwaffaq al-Dīn 'Abd Allāh Ibn Ahmad Ibn Qudāmah, al-Mughnī, vol. 14 (Arab Saudi: Dār 'Ālam al-Kutb, 1999), 78-79.

59 Muwaffaq al-Dīn 'Abd Allāh Ibn Aḥmad Ibn Qudāmah, al-Mughnī (Beirūt: Dār al-Fikr, 1983), 435-436.

60 Abū Hassan al-Māwardī, al-Aḥkām al-Sulțāniyah wa al-Wilāyah al-Dīnīyah (Beirūt: Dār al-Kutub al-'Ilmiyyah, 1985), 268.

${ }^{61}$ Abū Walid Ibrāhīm Ibn Muhammad Ibn Ab̄̄ al-Fadhal dikenali sebagai Ibn Shahnah al-Hanafì, Lissān al-Hukkām fì al-Ma rifat al-Aḥkām (Qāhirah: Maktabah Muștafā al-Bābī al-Ḥalābī, 1973), 219.

62 Ibn Abī al-Dam, Adāb al-Qadā' (Qāhirah: Dār al-Fikr, 1982), 464-466.

63 'Ala al-Dīn al-Tarābulusī, Mu'īn al-Hukkām fìmā Yataraddad bayna al-Khasmayn min al-Ahkām, 19. 
penghakiman perlu ditulis apabila berhadapan dengan tiga keadaan iaitu keadaan pertama ketika hukuman telah dijatuhkan ke atas penghutang penghakiman iaitu orang yang kena tuntut tetapi dia telah menghilangkan diri sebelum hukuman dijalankan dengan sempurna, keadaan kedua semasa perbicaraan penghutang penghakiman tidak hadir dan hukuman dijatuhkan, keadaan ketiga penghutang penghakiman hadir semasa perbicaraan tetapi sebelum sempat hukuman dijatuhkan dia telah melarikan diri. Maka dalam keadaan-keadaan ini, apabila dimohon oleh pemiutang penghakiman iaitu orang yang menuntut akan alasan penghakiman dan keputusan maka menjadi kemestian bagi hakim untuk menulis dan diserahkan kepadanya. ${ }^{64}$ Berdasarkan pendapat Sìdī Muhammad 'Ala' al-Dīn Afandī yang menyatakan bahawa penulisan penghakiman ini penting kerana terdapat padanya mașlahah, hal ini kerana pengakuan hakim mengenai sesuatu kes itu bukanlah suatu hujah kecuali tulisannya yang diterima untuk pelaksanaan. ${ }^{65}$

Kesimpulannya, penulisan penghakiman pada zaman Tābi'īn dan Tābi’ Tābi'īn mula berkembang disebabkan oleh keperluan-keperluan yang mendesak pada masa itu. Wilayah-wilayah Islam yang semakin luas dan bilangan penganut yang semakin ramai menyebabkan penulisan penghakiman diperlukan untuk mewujudkan keadilan kepada umat Islam. Walaupun masih di peringkat awal namun telah wujud peraturan dan perincian berkenaan dengan penulisan penghakiman. Justeru zaman ini telah menunjukkan penulisan penghakiman telah mempunyai kedudukan yang tersendiri walaupun masih lagi belum diaplikasikan secara keseluruhan dalam sistem kehakiman. Namun, usaha untuk mewujudkan satu tatacara dan prosedur penulisan dilihat sebagai satu usaha yang bagus oleh para ilmuan untuk memudahkan urusan penghakiman dijalankan dan dijadikan sebagai bukti serta rekod dalam perbicaraan.

\section{Zaman Sebelum Kemerdekaan}

Di Tanah Melayu, amalan penulisan dalam perundangan telah wujud sejak awal. Ketika pemerintahan Sultan Muzafar Shah, satu teks undang-undang Melayu telah dikanunkan dan dikenali dengan "Hukum Kanun Melaka". Ia merupakan teks yang lengkap mengenai hukum Syarak pada zaman itu, yang

\footnotetext{
64 Muwaffaq al-Dīn 'Abd Allāh Ibn Ahmad Ibn Qudāmah, Kitāb al-Mughnī (Mesir: Maktabah al-Qāhirah, 1970), 66.

65 Sīdī Muhammad 'Ala' al-Dīn Afandī, Hāsyiah Qurrah 'Uyyūn al-Akhyār Takmīlah Radd al-Mukhtār 'ala al-Dūrr al-Mukhtār (Beirūt: Dār al-Kutub al-'Ilmiyyah, 1994), 11.
} 
disertakan juga dengan hukum adat. Teks ini telah menjadi asas kepada teks Undang-undang Melayu di negeri-negeri Melayu seperti Undang-Undang Pahang, Johor, Selangor dan Kedah. ${ }^{66}$ Bahagian hukum Syarak dalam teks tersebut disusun mengikut Mazhab Shāfi‘ 1 . Teks Hukum Kanun Melaka boleh dianggap sebagai usaha pertama oleh pemerintah ketika itu untuk menetapkan bentuk undang-undang yang perlu dijadikan panduan termasuklah di dalamnya perincian mengenai hukum adat yang dijelaskan secara bertulis dan manuskrip lama. Justeru sekiranya ada penulisan penghakiman, hakim-hakim hendaklah berlandaskan kepada peruntukan dalam manuskrip ini. ${ }^{67}$

Berbanding penulisan penghakiman, catatan mengenai kes-kes yang berlaku pada zaman dahulu banyak tercatat. Misalnya semasa pemerintahan Sultan Alauddin Shah iaitu anak kepada Sultan Mansur Shah, telah tercatat: "Maka Sultan dengan Hang Siak pun pergi mengikut pencuri itu, ia lari ke atas Bukit Melaka. Maka diikut baginda ke atas bukit, bertemu di nagara bukit itu. Maka Sultan Alauddin bertempik lalu diparang baginda seorang, kena pinggangnya putus seperti mentimun, penggal dua. Maka yang empat orang itu lari ke jambatan. Maka diperturun oleh baginda, datang ke bawah bodi, maka keempatnya berbalik menghadap Sultan Alauddin. Maka dibunuh pula oleh baginda seorang lagi, dan yang tiga orang itu lari. Telah datang ke hujung jambatan, dibunuh oleh Hang Siak seorang, dua orang lagi itu terjun ke air, lalu berenang ke seberang". ${ }^{68}$ Antara contoh catatan kes yang lain ialah "pada suatu malam Seri Maharaja berkawal, bertemu dengan seorang pencuri. Maka diparang oleh Seri Maharaja dengan pedang bertupai, putus bahunya. Maka tangannya tersampai kepada alang kedai itu. Telah hari siang, maka perempuan yang punyai kedai itu hendak berkedai. Maka dilihatnya lengan orang tersampai pada alang kedainya. Maka ia pun terkejut lalu lari berteriakteriak. Maka daripada hari itulah datang kepada akhirnya tiada pencuri lagi di dalam negeri Melaka. ${ }^{69}$

Kemudiannya, Tanah Melayu telah mula dijajah oleh Portugis, Belanda, Inggeris dan Jepun. Walaupun setiap penjajah tersebut telah memperkenalkan undang-undang masing-masing namun hanya penjajah Inggeris yang banyak

\footnotetext{
66 Abdul Monir Yaacob, 'Ke Arah Mewujudkan Kerangka Perundangan Syariah yang Lebih Lengkap di Malaysia' dalam Asas dan Kerangka Perundangan Negara Islam, ed. Siti Shamsiah Md Supi (Kuala Lumpur: IKIM, 2005), 1-2.

${ }^{67}$ Abdul Monir Yaacob, 'Ke Arah Mewujudkan Kerangka Perundangan Syariah yang Lebih Lengkap di Malaysia,' 2.

68 Shellabear W.G., Sejarah Melayu (Kuala Lumpur: Fajar Bakti, 1981), 128.

69 Shellabear W.G., Sejarah Melayu, 129.
} 
membuat perubahan dalam sistem undang-undang di Tanah Melayu. ${ }^{70}$ Kedatangan Barat telah menjejaskan pentadbiran perundangan Islam $^{71}$ di mana undang-undang Inggeris dan prinsip-prinsip Common Law telah diserap melalui kes-kes yang diputuskan di mahkamah-mahkamah. ${ }^{72}$ Perkara ini dapat dilihat dalam kes Fatimah v. $\operatorname{Logan}^{73}$ apabila Hakim Hackett menyatakan, "bilamana pedagang Inggeris berpengkalan di sebuah negeri yang diduduki atau di sebuah negeri yang tidak bertamadun bukan sahaja pedagang Inggeris tersebut membawa bersama undang-undang mereka dari Tanah Besar ke Tanah Jajahan Baru, malah undang-undang Inggeris yang dibawa oleh mereka terpakai ke atas penduduk dan penghuni tanah jajahan baru tersebut". Kesan ini dapat dilihat dalam penulisan penghakiman yang dibuat dalam kes In The Goods of Abdullah, ${ }^{74}$ apabila Hakim Malkin R. memutuskan hukum berdasarkan kehendak si mati yang mahu melupuskan semua hartanya kepada waris tertentu sahaja sekalipun ia bercanggah dengan prinsip wasiat Islam. ${ }^{75}$

Daripada penulisan penghakiman di mahkamah Inggeris ini dapat disimpulkan bahawa Undang-undang Inggeris telah diberi pengiktirafan sekali gus sistem pentadbiran dan undang-undang Islam telah diketepikan. ${ }^{76}$ Hal ini dapat dilihat dalam Seksyen 3 Ordinan undang-undang Sivil (Perluasan) 1951 menyatakan:

"Dari tarikh Ordinan ini berkuatkuasa, maka pihak mahkamah hendaklah menerima pakai Common Law of England dan rukunrukun ekuiti sebagaimana yang dilaksanakan di England. Oleh itu segala peruntukan yang telah dibuat atau sebarang undangundang bertulis yang berkuatkuasa di Negeri-negeri Melayu

70 Zaini Nasohah, 'Penjajahan Inggeris dan Kedudukan Undang-undang Tempatan', dalam Pentadbiran Undang-undang Islam di Malaysia Sebelum dan Menjelang Merdeka (Kuala Lumpur: Utusan Publications dan Distributors Sdn Bhd, 2004), 19.

71 Mahmood Zuhdi Abdul Majid, Pengantar Undang-Undang Islam di Malaysia, 5253; Abd Jalil Borham, Sejarah Perundangan Islam di Malaysia (Kuala Lumpur: Penerbit Amal, 1993) 46.

72 Mahmood Zuhdi Abdul Majid, Pengantar Undang-Undang Islam di Malaysia, 56.

73 Fatimah v. Logan (1871) 1 Ky. 255.

74 In The Goods of Abdullah (1835) 2 Ky. 8.

75 Zaini Nasohah, 'Penjajahan Inggeris dan Kedudukan Undang-undang Tempatan', 21.

76 Mahmood Zuhdi Abdul Majid, Pengantar Undang-Undang Islam di Malaysia, 57 dan 59 . 


\section{Bersekutu atau negeri-negeri yang lain akan diganti dan diterima pakai undang-undang tersebut."}

Melainkan dalam persoalan undang-undang peribadi, undang-undang Islam diiktiraf ${ }^{77}$ di mana Sultan sebagai Ketua Agama Islam dan hakimhakim akan merujuk kepada buku-buku mengenai Islam dan juga maklumat daripada para kadi. ${ }^{78}$ Dalam kes Awee v. Ibrahim, ${ }^{79}$ diputuskan bahawa Sultan ialah ketua agama Islam dan boleh memberi kuasa kepada Kadi dan Penolong Kadi dalam semua perkara berkaitan agama Islam, perkahwinan dan perceraian. Berdasarkan penulisan penghakiman pada masa itu, hakim-hakim telah memutuskan kes-kes peribadi orang Islam berdasarkan hukum Syarak. Malah dalam kes Ramah v. Laton, ${ }^{80}$ Mahkamah Rayuan telah memutuskan bahawa Undang-undang Islam adalah undang-undang negeri dan mahkamah hendaklah mengiktiraf dan menggunakan undang-undang tersebut. ${ }^{81}$ Justeru dalam kes-kes di Negeri-negeri Melayu, hukum Syarak menjadi rujukan bagi orang Islam. Misalnya dalam kes Siti binti Yatim v. Mohamed Nor, ${ }^{82}$ Hakim Burton.J berpendapat bahawa wasiat yang memberi keutamaan kepada seseorang ahli waris dengan memberi bahagian yang lebih daripada bahagian yang sepatutnya adalah tidak sah kerana tidak mendapat persetujuan ahli-ahli waris lain.

Berdasarkan perbincangan di atas, catatan pada zaman pemerintahan Rajaraja Melayu lebih berbentuk catatan kes. Pada zaman penjajahan barat, barulah penulisan penghakiman yang lebih tersusun dimulakan. ${ }^{83}$ Berdasarkan catatan inilah, kesimpulan dapat dilakukan bahawa mereka banyak memasukkan elemen perundangan barat berbanding hukum syarak. ${ }^{84}$

\footnotetext{
77 Abdul Monir Yaacob, 'Ke Arah Mewujudkan Kerangka Perundangan Syariah yang Lebih Lengkap di Malaysia,' 338-339.

78 Mahmood Zuhdi Abd. Majid, Pengantar Undang-Undang Islam di Malaysia, 158. R.O Winstedt, The Malay Annals. (JMBRAS:1938), 16 (3), 129.

79 Awee v. Ibrahim (1916) 1 F.M.S.L.R. 274-275.

80 Ramah v. Laton (1927) 6 F.M.S.L.R. 128-131.

81 Ahmad Ibrahim, 'Konsep Perundangan Islam dan Penghayatannya di Malaysia' dalam Pentadbiran Undang-Undang Islam di Malaysia (Kuala Lumpur: IKIM, 1997), 1.

82 Siti binti Yatim v. Mohamed Nor (1928) 6 F.M.S.L.R. 135-137.

83 Ahmad Ibrahim, Sistem Kehakiman Islam di Malaysia Masa Kini,' Jurnal Hukum, ix/i (1994): 2.

84 Abdullah@Alwi Hj Hassan, 'Pelaksanaan Undang-Undang Syariah Pada Zaman Pramerdeka: Aspek Sejarah dan Pelaksanaannya' dalam Asas dan Kerangka Perundangan Negara Islam, ed. Siti Shamsiah Md Supi (Kuala Lumpur: IKIM, 2005), 46.
} 


\section{Zaman Selepas Kemerdekaan}

Selepas Tanah Melayu mencapai kemerdekaan, kedudukan Mahkamah Syariah menjadi lebih kukuh dan diiktiraf sehingga dibahagikan Mahkamah Syariah kepada tiga peringkat iaitu Mahkamah Rayuan Syariah (MRyS), Mahkamah Tinggi Syariah (MTS) dan Mahkamah Rendah Syariah (MRS). ${ }^{85}$ Pada masa yang sama juga sesetengah negeri telah menggubal enakmenenakmen khusus berkenaan pentadbiran undang-undang ${ }^{86}$ misalnya Undangundang Acara Mal, Undang-undang Acara Jenayah dan Undang-undang Keterangan bagi Mahkamah Syariah. ${ }^{87}$ Maka dari situ lahir pelbagai enakmenenakmen pentadbiran undang-undang Islam yang menyentuh tentang tatacara penghakiman dalam kes mal dan kes jenayah seperti Enakmen Pentadbiran Hukum Syarak Selangor 1952, ${ }^{88}$ dan Enakmen Pentadbiran Hukum Syarak Melaka 1959. ${ }^{89}$

Enakmen-enakmen ini ada memperuntukkan tentang rekod rayuan yang perlu disediakan antaranya salinan alasan keputusan yang diperlukan sebelum perbicaraan rayuan dimulakan. ${ }^{90}$ Mengulas mengenai kepentingan penulisan penghakiman, Salleh Buang ada menyatakan: ${ }^{91}$

"Walau tinggi mana pun ilmu seorang Hakim Mahkamah Syariah dalam perkara hukum, walau bagaimana jelas sekalipun fakta kes yang mungkin telah sebenarnya dibuktikan dalam perbicaraan, dan walaupun adil dan bertepatan di sisi hukum syarak sesuatu keputusan mahkamah itu, tetapi jika dalam rekod atau catatan mahkamah itu fakta kes sepenuhnya tidak direkod, disalin atau dicatat secara terperinci oleh hakim akan menyebabkan pihak yang kalah (sama ada dalam kes sivil mahupun jenayah) tidak akan dapat mengetahui sejauh mana fakta kes yang telah diterima

85 Enakmen Pentadbiran Mahkamah Syariah Kelantan 1982 (No. 3/1982); Enakmen Pentadbiran Mahkamah Syariah Kedah 1985 (No. 6/1985); Enakmen Pentadbiran Perundangan Islam Selangor 1989 (No. 2/1989).

86 Mahmood Zuhdi Abdul Majid, Pengantar Undang-Undang Islam di Malaysia, 76.

87 Ahmad Ibrahim, Konsep Perundangan Islam dan Penghayatannya di Malaysia, 14.

88 Enakmen Pentadbiran Hukum Syarak Selangor 1952 (No. 3/1952)

89 Enakmen Pentadbiran Hukum Syarak Melaka 1959 (No. 1/1959)

90 Seksyen 71 dan 90 Enakmen Pentadbiran Hukum Syarak Selangor 1952 (No. 3/1952). Seksyen 65 dan 84 Enakmen Pentadbiran Hukum Syarak Melaka 1959 (No. 1/1959).

91 Salleh Buang, 'Penghukuman: Satu Pandangan Ringkas untuk Hakim di Mahkamah Syariah di Malaysia,' Jurnal Hukum, vi/i (1988): 63. 
dan diambil kira oleh hakim bagi mahkamah membuat sesuatu keputusan, dan dia akan terus rasa terkilan dan tidak berpuas hati. Kesulitan dan perasaan tidak puas hati ini akan bertambah lagi apabila dia merayu kepada mahkamah yang lebih tinggi, kerana tanpa rekod perbicaraan yang baik dia tidak berupaya membuat rayuannya dengan baik. Begitu juga mahkamah yang mendengar rayuan akan menghadapi kesulitan untuk menimbangkan sama ada keputusan yang dibuat oleh hakim yang membicarakan kes itu betul ataupun salah..."

Bertepatan dengan kepentingan ini, maka tidak hairanlah Seksyen 130(1) Akta Tatacara Mal Mahkamah Syariah (Wilayah-Wilayah Persekutuan) 1998 memperuntukkan:

\section{"Tiap-tiap hakim perbicaraan hendaklah menyampaikan penghakiman bertulis." 92}

Dalam kenyataan di atas dapat difahami bahawa penulisan penghakiman ini amat penting lebih-lebih lagi berkaitan prosiding rayuan. Ini kerana berdasarkan amalan, perayu hanya boleh mempertikai sesuatu keputusan atau penghakiman hanya dengan wujudnya penulisan penghakiman..$^{93} \mathrm{Hal}$ ini kerana, pihak perayu perlu memberi alasan penghakiman yang telah dibuat oleh Hakim Bicara kepada Mahkamah Rayuan, malah para hakim di Mahkamah Rayuan juga akan merujuk kandungan teks penghakiman di peringkat perbicaraan kerana ia hanya bergantung pada keterangan-keterangan yang dicatat oleh hakim perbicaraan di samping membuat rujukan ke atas keskes terdahulu dan sumber hukum syarak. ${ }^{94}$ Adapun menurut Mohd Nadzri Abdul Rahman, penulisan penghakiman adalah penting kerana ia membantu hakim memutuskan kes dengan tepat melalui analisis yang dibuat. ${ }^{95}$ Perkara ini boleh dilihat dalam peruntukan undang-undang berkenaan rayuan dengan

92 Akta Tatacara Mal Mahkamah Syariah (Wilayah-Wilayah Persekutuan) 1998, (Akta No. 585, 1998).

93 Suwaid Tapah, 'Penulisan Teks Penghakiman Kes-Kes Mal di Mahkamah Syariah' dalam Penulisan Teks Penghakiman di Mahkamah Syariah, ed. Ruzman Md. Noor (Kuala Lumpur: Universiti Malaya, 2008), 46.

94 Faiza Tamby Chik, 'Perbandingan Kaedah Penulisan Teks Penghakiman' dalam Penulisan Teks Penghakiman di Mahkamah Syariah, ed. Ruzman Md. Noor (Kuala Lumpur: Universiti Malaya, 2008), 42.

95 Mohd Nadzri Abdul Rahman (Yang Arif, Hakim Mahkamah Tinggi Syariah Seremban, Negeri Sembilan, sekarang telah ditugaskan sebagai Pengarah Kehakiman di Jabatan Kehakiman Syariah Malaysia) dalam temu bual dengan penulis, pada 4 Disember 2014. 
merujuk Seksyen 142(1) Akta Tatacara Mal Mahkamah Syariah (WilayahWilayah Persekutuan) 1998 menyatakan bahawa:

"Peguam perayu perlu menyediakan bilangan salinan rekod rayuan yang dikehendaki dan rekod itu hendaklah mengandungi salinan pliding, nota keterangan, alasan penghakiman, notis rayuan, alasan rayuan, semua ekshibit dokumentar dan senarai ekshibit bukan dokumentar dan diberikan kepada mahkamah.” 96

Seksyen 139(5) Akta itu juga memperuntukkan bahawa:

"Mahkamah yang terhadap keputusannya rayuan itu dibuat hendaklah, apabila menerima notis rayuan itu dan apabila dibayar fi yang ditetapkan, membekalkan kepada perayu salinan diperakui bagi nota-nota keterangan dan penghakiman." 97

Tambahan lagi, penulisan penghakiman ini juga penting untuk ditulis, dicatat atau direkodkan kerana terdapat suatu sistem hierarki mahkamah yang menghendaki semua kes perlu dibicarakan di mahkamah yang lebih rendah terlebih dahulu. Maka perlu ada alasan penghakiman jika kes tersebut hendak dirujuk kepada peringkat mahkamah yang lebih tinggi. ${ }^{98}$ Selain untuk tujuan rayuan, penulisan penghakiman ini juga perlu dibuat untuk menjelaskan hujah hakim, rujukan bagi pihak-pihak yang bertikai, semakan, untuk kajian dan sebagainya. ${ }^{99}$ Oleh itu, kepentingan penulisan penghakiman seterusnya ialah menjelaskan hujah hakim dalam menyatakan sumber-sumber yang digunakan sehingga menghasilkan keputusan dan hukuman yang menunjukkan bahawa ia bukan semata-mata mengikut hawa nafsu, bahkan dapat memberi pengetahuan kepada pihak yang dihukum berkenaan dengan sebab hukuman itu dijatuhkan ke atasnya serta pihak-pihak yang terlibat supaya wujudnya keadilan dalam penghakiman. Oleh itu, hakim mesti menyediakan penulisan penghakiman

96 Akta Tatacara Mal Mahkamah Syariah (Wilayah-Wilayah Persekutuan) 1998, (Akta No. 585, 1998).

97 Akta Tatacara Mal Mahkamah Syariah (Wilayah-Wilayah Persekutuan) 1998, (Akta No. 585, 1998).

98 Ahmad Hidayat Buang, 'Penulisan Teks Penghakiman dalam Perundangan Islam,' 3.

99 Ahmad Ibrahim, 'Konsep Perundangan Islam dan Penghayatannya di Malaysia,' 117-130. 
kerana ia merupakan salah satu cara bagi menentukan prestasi semua hakimhakim termasuk ketua Hakim Syarie. ${ }^{100}$

Selain itu, penulisan penghakiman itu penting dalam perlaksanaan perintah dan hukuman jika pihak yang dikehendaki melakukan perbuatan tersebut tidak hadir sewaktu hukuman dijatuhkan atau tidak diwakili. ${ }^{101}$ Terdapat peruntukan yang berkait, iaitu Seksyen 135(3) Akta Tatacara Mal Mahkamah Syariah (Wilayah-Wilayah Persekutuan) 1998 yang menjelaskan bahawa:

\section{"Jika orangyang dikehendaki melakukan perbuatanitu tidakhadir sendiri atau tidak diwakili, tiada prosiding untuk penangkapan atau pengkomitannya boleh diambil, melainkan jika suatu salinan penghakiman atau perintah itu yang diendorskan dengan notis dalam Borang MS28 telah disampaikan kepadanya." 102}

Oleh yang demikian, jika penulisan penghakiman ini tidak dibuat maka pihak-pihak yang tidak hadir pada hari keputusan kes itu dibuat tidak akan dapat mengetahui tindakan-tindakan yang dikenakan padanya atau yang perlu dilakukan olehnya dalam kes tersebut. Justeru penghakiman tersebut perlu disampaikan kepadanya. Selanjutnya, penulisan penghakiman boleh dijadikan sebagai panduan bagi mahkamah itu sendiri atau menjadi ikutan untuk mahkamah yang lebih rendah di masa hadapan. ${ }^{103}$ Hal ini kerana, penulisan penghakiman Mahkamah Rayuan boleh dijadikan panduan dan ikutan bagi mahkamah-mahkamah di bawahnya. ${ }^{104}$ Maka tidak dapat tidak, Hakim Mahkamah Rayuan perlu menulis penghakiman, berdasarkan Seksyen 145 Akta tersebut yang memperuntukkan:

"Mahkamah yang mendengar rayuan hendaklah menyatakan alasan penghakimannya secara bertulis". ${ }^{105}$

100 Mohd Nadzri Abdul Rahman (Yang Arif, Hakim Mahkamah Tinggi Syariah Seremban, Negeri Sembilan, sekarang telah ditugaskan sebagai Pengarah Kehakiman di Jabatan Kehakiman Syariah Malaysia) dalam temu bual dengan penulis, pada 4 Disember 2014.

101 Ahmad Hidayat Buang, 'Penulisan Teks Penghakiman dalam Perundangan Islam', 12.

102 Akta Tatacara Mal Mahkamah Syariah (Wilayah-Wilayah Persekutuan) 1998, (Akta No. 585, 1998).

103 Ahmad Ibrahim, 'Nota Perbicaraan dan Penghakiman' dalam Pentadbiran Undang-Undang Islam di Malaysia (Kuala Lumpur: IKIM, 1997), 128-129.

104 Suwaid Tapah, 'Penulisan Teks Penghakiman Kes-Kes Mal di Mahkamah Syariah', 47.

105 Akta Tatacara Mal Mahkamah Syariah (Wilayah-Wilayah Persekutuan) 1998, (Akta No. 585, 1998). 
Penulisan penghakiman yang direkodkan boleh membantu hakim sebagai panduan dalam prosiding penghakiman juga boleh dijadikan sebagai rujukan ilmiah kepada ahli akademik. ${ }^{106}$

\section{KAEDAH PENULISAN PENGHAKIMAN}

Kaedah penulisan penghakiman pada awalnya masih lagi belum mempunyai garis panduan yang khusus. Justeru, pada tahun 1997, Ahmad Ibrahim yang merupakan tokoh undang-undang Islam di Malaysia dan diktiraf sebagai bapa undang-undang Malaysia telah mencadangkan beberapa kaedah atau garis panduan penulisan penghakiman. Dalam cadangan beliau, untuk menulis penghakiman mestilah menyatakan beberapa perkara berikut iaitu mengulas fakta yang diterima dan fakta yang tidak diterima, menyatakan peruntukan undang-undang yang digunakan, menyatakan beban pembuktian seseorang dalam kes, berat pembuktian yang diperlukan sama ada sesuatu unsur dalam kes jenayah atau sesuatu isu dalam kes sivil yang dibuktikan, keputusan atas setiap unsur atau isu, penghakiman atau keputusan dan dalam kes jenayah perlu menyatakan alasan mengapa suatu hukuman itu dijatuhkan. ${ }^{107}$

Seterusnya pada tahun 2001, pihak Jabatan Kehakiman Syariah Malaysia telah mengambil inisiatif untuk melakukan penambahbaikan dengan mewujudkan satu arahan berkaitan garis panduan penulisan alasan penghakiman malah turut dikuatkuasakan agar pengaplikasiannya selaras bagi setiap Hakim Syarie di setiap negeri. Oleh itu dalam Arahan Amalan No. 6 Tahun 2001 yang telah dikuatkuasakan serta-merta menyatakan bahawa Mesyuarat Arahan Amalan Mahkamah Syariah seluruh Malaysia dan keputusan Mesyuarat Ketua-ketua Hakim Syarie telah bersetuju dan mengesahkan untuk menerima pakai arahan Alasan penghakiman dan ianya hendaklah menyentuh isu yang dibangkitkan, pemakaian undang-undang, hukum syarak, pentafsiran dan ulasan ke atas hujah-hujah pihak-pihak serta autoriti kes yang dirujuk. Adapun semasa penulisan dibuat penggunaan tanda tulisan yang betul seperti perenggan, koma, noktah, pengikat kata, seruan dan sebagainya hendaklah diikuti. $^{108}$

Selanjutnya, pada tahun 2011 pula, pihak Jabatan Kehakiman Syariah Malaysia sekali lagi telah membuat penambahbaikan dengan mengemaskini hal-hal yang berkaitan dengan garis panduan penulisan alasan penghakiman

106 Ahmad Hidayat Buang, 'Penulisan Teks Penghakiman dalam Perundangan Islam', 12.

107 Ahmad Ibrahim, 'Nota Perbicaraan dan Penghakiman', 128-129.

108 Arahan Amalan No. 6 Tahun 2001. 
agar ia lebih terperinci dan lengkap. Dalam hal ini, Mesyuarat Jawatankuasa Induk Arahan Amalan Mahkamah Syariah telah mengeluarkan garis panduan lengkap Penulisan Teks Penghakiman dalam Arahan Amalan No. 11 Tahun 2011 yang mesti mengandungi tajuk penghakiman berdasarkan peringkat mahkamah, keputusan hakim dalam kes tersebut, rujukan dalam teks, rujukan kepada petikan al-Quran, rujukan kepada petikan hadis, rujukan kepada undangundang, rujukan kepada matan kitab, rujukan kepada kes yang telah diputuskan, rujukan artikel dan cara penulisan berkaitan Akta, Seksyen, penghakiman, ayat al-Quran, terjemahan ayat al-Quran, hadis dan Arahan Amalan. ${ }^{109}$ Justeru, para Hakim Syarie perlu menyediakan alasan penghakiman tertakluk kepada Garis Panduan Penulisan Teks Penghakiman yang telah dikuatkuasakan dalam Arahan Amalan tersebut sehingga ke hari ini. Dengan adanya garis panduan ini dapat meyakinkan lagi bahawa penghakiman sesuatu kes itu perlu ditulis bahkan perlu mengikut garis panduan penulisan penghakiman yang telah disediakan bagi mengelak berlakunya masalah kekeliruan dan penulisan yang tidak seragam. Lantaran itu, penulisan penghakiman yang sistematik dan teratur juga akan memudahkan orang ramai untuk merujuk dan memahami sesuatu penghakiman itu sekali gus memperlihatkan kewibawaan para hakim dalam menegakkan keadilan.

Kesimpulan daripada perbincangan di atas telah menjelaskan tentang amalan penulisan penghakiman di Malaysia yang telah menjadi prasyarat yang penting dalam prosiding kehakiman. Pelbagai panduan dan tatacara penulisan telah diperkenalkan dari semasa ke semasa untuk memastikan kualiti penulisan dipertingkatkan. Penulisan bukan sahaja penting dalam memastikan keadilan dapat ditegakkan berdasarkan alasan penghakiman yang diutarakan tetapi juga untuk menyenangkan sesuatu kes dibawa ke mahkamah yang lebih tinggi. Di samping itu juga penulisan penghakiman membantu dalam urusan merekod dan boleh dijadikan sebagai rujukan oleh ahli akademik dan mereka yang berada dalam bidang kehakiman.

\section{AMALAN PELAKSANAAN PENULISAN PENGHAKIMAN DI MAHKAMAH SYARIAH}

Amalan penulisan penghakiman telah berlaku di Mahkamah Syariah sebelum wujudnya garis panduan yang khusus dalam penulisannya. Namun, terdapat beberapa kelemahan terhadap catatan tersebut dan memerlukan kepada penambaikan sehingga wujudnya Arahan Amalan berkenaan garis panduan penulisan penghakiman. Jadual 1 menunjukkan pelaksanaan penulisan

109 Arahan Amalan No. 11 Tahun 2011. 
penghakiman berdasarkan tahun yang menunjukkan perbezaan amalan sebelum dan selepas Arahan Amalan garis panduan penulisan penghakiman dikuatkuasakan.

Jadual 1: Pelaksanaan Penulisan Penghakiman Berdasarkan Tahun

\begin{tabular}{|c|c|c|c|c|c|}
\hline $\begin{array}{c}\text { Garis } \\
\text { Panduan } \\
\text { Penulisan } \\
\text { Penghakiman }\end{array}$ & $\begin{array}{l}\text { Rusidah bt. } \\
\text { Abdul Ghani } \\
\text { lwn. Pendakwa } \\
\text { Jabatan Agama } \\
\text { Islam, Wilayah } \\
\text { Persekutuan } \\
\text { (1990) }\end{array}$ & $\begin{array}{c}\text { Ismail b. } \\
\text { Ishak } \\
\text { Iwn. Kalam } \\
\text { bt Mamat } \\
\text { (1995) }\end{array}$ & $\begin{array}{c}\text { Permohonan } \\
\text { Perisytiharan } \\
\text { Status Agama } \\
\text { Janisah bt. } \\
\text { Abd Rahim } @ \\
\text { Bigul } \\
\text { (2004) }\end{array}$ & $\begin{array}{c}\text { Noor } \\
\text { Kamal b. } \\
\text { Mohammad } \\
\text { lwn. Rusnah } \\
\text { bt. Drauh } \\
\text { (2012) }\end{array}$ & $\begin{array}{c}\text { Hasmah } \\
\text { bt. Md Ali } \\
\text { lwn. Abd } \\
\text { Ghani b. } \\
\text { Harun } \\
\text { (2013) }\end{array}$ \\
\hline $\begin{array}{l}\text { Kepala kes } \\
\text { (Tempat } \\
\text { perbicaraan, } \\
\text { No.kes, Nama } \\
\text { hakim, tarikh } \\
\text { perbicaraan) }\end{array}$ & Ada & Ada & Ada & Ada & Ada \\
\hline Abstrak & Ada & Ada & Ada & Ada & Ada \\
\hline Fakta Kes & Ada & Ada & Ada & Ada & Ada \\
\hline Keputusan & Ada & Ada & Ada & Ada & Ada \\
\hline Peguam Syarie & Tiada & Tiada & Tiada & Ada & Ada \\
\hline $\begin{array}{l}\text { Senarai } \\
\text { Rujukan }\end{array}$ & Tiada & Tiada & Ada & Ada & Ada \\
\hline $\begin{array}{c}\text { Alasan } \\
\text { Penghakiman }\end{array}$ & Ada & Ada & Ada & Ada & Ada \\
\hline $\begin{array}{c}\text { keputusan } \\
\text { perintah }\end{array}$ & Ada & Ada & Ada & Ada & Ada \\
\hline $\begin{array}{c}\text { Penomboran } \\
\text { perenggan } \\
(1,2,3 . .)\end{array}$ & Tiada & Tiada & Tiada & Ada & Ada \\
\hline $\begin{array}{c}\text { Penomboran } \\
\text { perenggan } \\
\text { dalam perintah }\end{array}$ & Tiada & Ada & Tiada & Ada & Ada \\
\hline $\begin{array}{c}\text { Rujukan } \\
\text { dicondongkan }\end{array}$ & Tiada & Ada & Ada & Ada & Ada \\
\hline
\end{tabular}

Jadual 1 menunjukkan tentang perbezaan amalan pelaksanaan penulisan penghakiman di Mahkamah Syariah. Dalam jadual tersebut telah dilampirkan kes-kes berdasarkan tahun sebelum dikuatkuasakan garis panduan penulisan 
penghakiman sehingga telah dikuatkuasakan dalam Arahan Amalan No. 11 Tahun 2011. Dalam kes Rusidah bt Abdul Ghani lwn. Pendakwa Jabatan Agama Islam, Wilayah Persekutuan ${ }^{110}$ jelas menunjukkan masih banyak kekurangan dari aspek penulisan seperti tiada catatan senarai peguam yang terlibat, senarai rujukan sama ada kitab, undang-undang atau kes walaupun dalam kes ada menggunakan rujukan undang-undang juga tidak dicondongkan. Dari segi penomboran, langsung tidak ditulis nombor perenggan dan nombor perenggan dalam perintah.

Seterusnya pada kes Ismail bin Ishak lwn. Kalam bt Mamat ${ }^{111}$ telah berlaku sedikit penambahbaikan dalam penulisan. Walau bagaimanapun penulisan penghakiman pada masa ini masih lagi belum mempunyai garis panduan yang khusus. Manakala dalam kes Permohonan Perisytiharan Status Agama Janisah bt.AbdRahim@Bigul, ${ }^{112}$ penulisan bertambah baik dan lebih lengkap. Hal ini, kerana pada tahun 2001 telah diperkenalkan satu Arahan Amalan No. 6 Tahun 2001 yang mengandungi garis panduan penulisan penghakiman secara ringkas yang hanya menyentuh berkenaan dengan isu yang dibangkitkan, pemakaian undang-undang, Hukum Syarak, pentafsiran dan ulasan ke atas hujah-hujah pihak-pihak, Otoriti kes yang dirujuk. Semasa penulisan dibuat penggunaan tanda tulisan yang betul seperti perenggan, koma, noktah, pengikat kata, seruan dan sebagainya perlu dipatuhi.

Selanjutnya, selepas Arahan Amalan No. 11 Tahun 2011 dikuatkuasakan, penulisan pennghakiman dilihat lebih lengkap dan kemas dengan mengikut garis panduan penulisan penghakiman yang diberikan. Hal ini dapat dilihat dalam kes Noor Kamal bin Mohammad lwn. Rusnah bt Drauh ${ }^{113}$ dan kes Hasmah bt Md Ali lwn. Abd Ghani bin Harun. ${ }^{114}$

\section{KESIMPULAN}

Secara kesimpulannya, penulisan penghakiman tidak dinyatakan secara khusus dalam al-Quran, tetapi menjadi keperluan dalam menghadapi perkembangan

110 Rusidah bt. Abdul Ghani lwn. Pendakwa Jabatan Agama Islam, Wilayah Persekutuan, Jurnal Hukum, VII/II (1991): 209-212.

111 Ismail bin Ishak lwn. Kalam bt. Mamat, Jurnal Hukum, IX/I (1994): 41-44.

112 Permohonan Perisytiharan Status Agama Janisah bt. Abd Rahim@Bigul, Jurnal Hukum, XXII/I (2006): 67-69.

113 Noor Kamal bin Mohammad lwn. Rusnah bt. Drauh, Jurnal Hukum, 38/1 (2014): 118-124.

114 Hasmah bt. Md Ali lwn. Abd Ghani bin Harun, Jurnal Hukum, 37/1 (2013): 116125. 
sistem kehakiman Islam semasa. Bertepatan dengan gesaan al-Quran yang mengharuskan supaya menulis dan mencatat segala perkara yang berkaitan dengan hutang walaupun hutang itu dalam jumlah yang sedikit. Dapat difahami juga berdasarkan dalil ini, sebab penulisan hutang dilakukan adalah untuk mengelakkan keraguan bagi mencapai keadilan. Tujuannya jika terdapat pertikaian, bukti bertulis boleh dirujuk. Maka demikian juga jika keputusan kehakiman mendapat pertikaian ke mahkamah yang lebih tinggi, penulisan alasan penghakiman dapat dijadikan sandaran hujah. Tambahan lagi, dalam konteks perundangan, keadilan merupakan matlamat utama yang hendak dicapai dalam sesuatu penghakiman. Oleh yang demikian, Mahkamah Syariah perlu mematuhi dan mengikuti kaedah serta prosedur yang telah ditetapkan dalam menulis penghakiman supaya ianya menjadi lengkap dan kemas sekali gus menampakkan pengurusan Mahkamah Syariah Malaysia yang lebih efisien dalam menjalankan tanggungjawab yang diamanahkan.

\section{RUJUKAN}

'Ala al-Dīn al-Tarābulusī, Mu'īn al-Hukkām fìmā Yataraddad bayna alKhasmayn Min al-Aḥkām (Qāhirah: Maktabah Mușțāfā al-Bābī alHalābī, 1973).

'Imad al-Dīn Abī al-Fidā' Ismā'īl Ibn 'Umar Ibn Kathīr, Tafsīr al-Qur'ān al'Azịm: al-Ma'rūf bī al-Tafsìr Ibn Kathīr, vol. 1 (al-Riyāḍ: Dār al-Salām li al-Nashr wa al-Tawzī', 2004).

'Imād al-Dīn Abī al-Fidā' Ismā'īl Ibn Kathīr, Tafsīr al-Qur'ān al- 'Ażīm, vol. 2 (Beirūt: Dār al-Andalus, 1966).

Abd Jalil Borham, Sejarah Perundangan Islam di Malaysia (Kuala Lumpur: Penerbit Amal, 1993).

Abdul Monir Yaacob, 'Ke Arah Mewujudkan Kerangka Perundangan Syariah yang Lebih Lengkap di Malaysia' dalam Asas dan Kerangka Perundangan Negara Islam, ed. Siti Shamsiah Md Supi (Kuala Lumpur: IKIM, 2005).

Abdullah@Alwi Hj Hassan, 'Pelaksanaan Undang-Undang Syariah Pada Zaman Pramerdeka: Aspek Sejarah dan Pelaksanaannya' dalam Asas dan Kerangka Perundangan Negara Islam, ed. Siti Shamsiah Md Supi (Kuala Lumpur: IKIM, 2005).

Ab̄̄ Bakr Aḥmad Ibn al-Husayn Ibn 'Alī al-Bayhaqī, Sunan al-Kab̄̄r, vol. 20 (Qāhirah: T.p., 2011).

Abū Dāwud Sulaymān Ibn Ash'ath al-Azadī al-Sijistānī, Sunan Abī Dāwud, Kitāb al-'Ilm, Bab fĩ Kitāb al-'Ilm, no. Hadis 3646. 
Abū Hassan al-Māwardī, al-Aḥkām al-Sulțāniyyah wa al-Wilāyah al-Dīnīyah (Qāhirah: Matba'ah Muștāfā al-Bābī al-Ḥalābī, 1966).

Abū Hassan al-Māwardī, al-Aḥkām al-Sulțāniyyah wa al-Wilāyah al-Dīnīyah (Beirūt: Dār al-Kutub al-'Ilmiyyah, 1985).

Abū Hassan al-Māwardī, al-Hāwwì al-Kabīr, vol. 16 (Beirūt: Dār al-Kutub al'Ilmiyyah, 2009).

Abū al-Ḥsayn Muslim Ibn al-Hajjāj Qushayrī al-Naysābūrī, Saḥ̄h Muslim, Kitāb al-'Ilm, no. Hadis 1355.

Abū 'Umar Muḥammad Ibn Yūsuf Ibn Ya'qūb al-Kindī, Kitāb al-Qudhāt alladhīn wallaw Qadhā' Misr (T.t.p: Madīnah Rumīyyah al-'Izmī, 1908).

Abū Walid Ibrāhīm Ibn Muhammad Ibn Ab̄̄ al-Fadhal dikenali sebagai Ibn Shahnah al-Hanafī, Lissān al-Hukkām fì al-Ma 'rifat al-Ahkām (Qāhirah: Maktabah Mușțāfā al-Bābī al-Halāb̄i, 1973).

Ahmad 'Abd al-Muniem al-Bahai, Tārīkh al-Qaḍ̄' fì al-Islām (Mesir: Matba'ah Lajnah al-Bayān al-'Arabī, 1970).

Ahmad Hidayat Buang, 'Penulisan Teks Penghakiman dalam Perundangan Islam,' dalam Penulisan Teks Penghakiman di Mahkamah Syariah, ed. Ruzman Md. Noor (Kuala Lumpur: Universiti Malaya, 2008).

Ahmad Ibrahim, 'Sistem Kehakiman Islam di Malaysia Masa Kini,' Jurnal Hukum, ix/i (1994).

Ahmad Ibrahim, 'Konsep Perundangan Islam dan Penghayatannya di Malaysia,' dalam Pentadbiran Undang-Undang Islam di Malaysia (Kuala Lumpur: IKIM, 1997).

Aḥmad Jawdah et al., Majallah al-Aḥkām al- 'Adliyyah (T.t.p.: T.p., 1968).

Aḥmad Sa'ad 'Alī, ed. Sunan Abī Dāwud, vol. 2 (Mesir: Mușțāfā al-Bābī alHalābī, 1952).

Amin al-Jarumi, Prinsip-Prinsip Prosiding Mahkamah dalam Syariat Islam (Shah Alam: Pusat Penerbitan Universiti UiTM, 2006).

Daud Muhammad, 'Peguam Syarie dalam Institusi Qada,' Jurnal Hukum, 26/2 (2008).

Daud Muhammad, 'Penulisan Teks Penghakiman di Mahkamah Syariah: Kaedah dan Pendekatan' dalam Penulisan Teks Penghakiman di Mahkamah Syariah, ed. Ruzman Md. Noor (Kuala Lumpur: Penerbit Universiti Malaya, 2008).

Faiza Tamby Chik, 'Perbandingan Kaedah Penulisan Teks Penghakiman,' dalam Penulisan Teks Penghakiman di Mahkamah Syariah, ed. Ruzman Md. Noor (Kuala Lumpur: Universiti Malaya, 2008).

Farid Sufian Shuaib, Administration of Islamic Law in Malaysia (Kuala 
Lumpur: Malayan Law Journal Sdn. Bhd., 2001).

Ghazali Abdullah, Jafril Khalil dan Mohd Nasran Mohammad, 'Isu Syariah dan Undang-Undang' dalam Pengantar Sistem Kehakiman Islam (Kuala Lumpur: Universiti Kebangsaan Malaysia, 1996).

Ibn Abī al-Dam, Adāb al-Qaḍā' (Qāhirah: Dār al-Fikr, 1982).

Ibn al-Qayyim al-Jawziyyah, A 'lam al-Muwaqqi 'ìn 'an Rabb al-'Ālamīn, vol. 1 (Qāhirah: Maktabah al-Kulliyyah al-Azhāriyyah, 1968).

Ibn Sa'ad, al-Tabaqāt al-Kubrā, vol. 2 (Beirūt: Dār Șadīr, 1957).

Ibrāhīm Najīb Muḥammad 'Iwad, al-Qaḍ̄'fì al-Islām Tārikhuhu wa Niẓāmuhu (Qāhirah: Majma‘ al-Buhūth al-Islāmiyyah, 1975).

M. Syuhudi Ismail, Kaedah Kesahihan Sanad Hadith (Selangor: Thinker's Library Sdn. Bhd, 1988).

Mahmood Zuhdi Abdul Majid, Pengantar Undang-Undang Islam di Malaysia (Kuala Lumpur: Universiti Malaya, 1997).

Mahmud Saedon Awang Othman, Institusi Pentadbiran Undang-Undang dan Kehakiman Islam (Kuala Lumpur: Dewan Bahasa dan Pustaka, 1996).

Mohd Nadzri Abdul Rahman Ibrahim, Undang-Undang Tatacara Mal Mahkamah Syariah: Prinsip dan Amalan (Negeri Sembilan: Karya Kreatif Resources, 2010).

Mohd Saleh Hj Ahmad, Pengantar Syariat Islam (Selangor: Pustaka Haji Abdul Majid, 2011).

Muhammad 'Abd al-Rahmān al-Bakr, al-Sulțah al-Qaḍ̄ 'iyyah wa Shakhșiyyah al-Qādì fì al-Niz̄ām al-Islāmī (Qāhirah: al-Zahrā' li al-I'lām al-'Arabī, 1988).

Muḥammad 'Abd al-Qādir Abū Fāris, al-Qadā' fì al-Islām ('Ammān: Dār alFūrqan, 1995).

Muḥammad Ibn 'Abd Allāh al-Khātib al-Tibriz̄i, Miskhāt al-Maṣābih, vol. 2 (Beirūt: al-Maktab al-Islāmī, 1996).

Muhạammad Idrīs al-Shāfi‘'̄al-Umm, vol. 6 (Beirūt: Dār al-Ma’rifah, 1973).

Muḥammad al-Syarbin̄̄ al-Khatīb, al-Iqnā’ fì Hāll Alfāz Abì Syujā ‘ (T.t.p: T.p, t.t.).

Muwaffaq al-Dīn 'Abd Allāh Ibn Aḥmad Ibn Qudāmah, al-Mughnī (Beirūt: Dār al-Fikr, 1983).

Muwaffaq al-Dīn 'Abd Allāh Ibn Aḥmad Ibn Qudāmah, al-Mughnī, vol. 14 ('Arab Saudi: Dār 'Ālam al-Kutb, 1999).

Muwaffaq al-Dīn 'Abd Allāh Ibn Aḥmad Ibn Qudāmah, Kitāb al-Mughnī (Mesir: Maktabah al-Qāhirah, 1970). 
R.O. Winstedt, The Malay Annals, 16/3, JMBRAS (1938).

Salahuddin Khuda Bakhsh, The Renaissance of Islam (Patna: Jubilee Printing and Publishing House, 1937).

Salleh Buang, 'Penghukuman: Satu Pandangan Ringkas untuk Hakim di Mahkamah Syariah di Malaysia,' Jurnal Hukum, vi/i (1988).

Shellabear W.G., Sejarah Melayu (Kuala Lumpur: Fajar Bakti, 1981).

Sīdī Muhammad 'Ala' al-Dīn Afandī, Hāsyiah Qurrah 'Uyyūn al-Akhyār Takmīlah Radd al-Mukhtār 'ala al-Dūrr al-Mukhtār (Beirūt: Dār alKutub al-'Ilmiyyah, 1994).

Suwaid Tapah, 'Penulisan Teks Penghakiman Kes-Kes Mal di Mahkamah Syariah' dalam Penulisan Teks Penghakiman di Mahkamah Syariah, ed. Ruzman Md. Noor (Kuala Lumpur: Universiti Malaya, 2008).

Zaini Nasohah, 'Pengenalan Undang-Undang bagi Orang Islam' dalam Pentadbiran Undang-undang Islam di Malaysia Sebelum dan Menjelang Merdeka (Kuala Lumpur: Utusan Publications dan Distributors Sdn. Bhd., 2004).

Zaini Nasohah, 'Penjajahan Inggeris dan Kedudukan Undang-undang Tempatan', dalam Pentadbiran Undang-undang Islam di Malaysia Sebelum dan Menjelang Merdeka (Kuala Lumpur: Utusan Publications dan Distributors Sdn. Bhd., 2004).

\section{Statut}

Akta Tatacara Mal Mahkamah Syariah (Wilayah-Wilayah Persekutuan) 1998. Arahan Amalan No. 6 Tahun 2001.

Arahan Amalan No. 11 Tahun 2011.

\section{Kes}

Hasmah bt. Md Ali lwn. Abd Ghani b. Harun, Jurnal Hukum, 37/1 (2013).

Ismail b. Ishak lwn. Kalam bt. Mamat, Jurnal Hukum, IX/I (1994).

Noor Kamal b. Mohammad lwn. Rusnah bt. Drauh, Jurnal Hukum, 38/1 (2014).

Permohonan Perisytiharan Status Agama Janisah bt. Abd Rahim @ Bigul, Jurnal Hukum, XXII/I (2006).

Rusidah bt. Abdul Ghani lwn. Pendakwa Jabatan Agama Islam, Wilayah Persekutuan, Jurnal Hukum, VII/II (1991). 


\section{Temu bual}

Mohd Nadzri Abdul Rahman (Yang Arif, Hakim Mahkamah Tinggi Syariah Seremban, Negeri Sembilan, sekarang telah ditugaskan sebagai Pengarah Kehakiman di Jabatan Kehakiman Syariah Malaysia) dalam temu bual dengan penulis, pada 4 Disember 2014. 
Jurnal Syariah, Jil. 24, Bil. 1 (2016) 25-58 